\title{
The Role of Regional Ecological Assessment in Quantifying Ecosystem Services for Forest Management
}

\author{
Lars Y. Pomara *(D) and Danny C. Lee \\ Southern Research Station, USDA Forest Service, 200 WT Weaver Blvd, Asheville, NC 28804, USA; \\ danny.c.lee@usda.gov \\ * Correspondence: lazarus.y.pomara@usda.gov
}

Citation: Pomara, L.Y.; Lee, D.C. The

Role of Regional Ecological

Assessment in Quantifying

Ecosystem Services for Forest Management. Land 2021, 10, 725.

https://doi.org/10.3390/

land 10070725

Academic Editors: Emilio Vilanova and Lord Ameyaw

Received: 1 June 2021

Accepted: 8 July 2021

Published: 9 July 2021

Publisher's Note: MDPI stays neutral with regard to jurisdictional claims in published maps and institutional affiliations.

\begin{abstract}
Regional ecological assessments evaluate sustainability as an interaction among ecosystem services and stressors across changing landscapes. Using ecological assessments to inform ecosystem management activities relies on assessing functional linkages between ecosystem processes and ecosystem services, because ecosystem processes are the primary targets of ecosystem management. We undertook a review of regional ecological assessments in the Appalachian region of the United States to examine how forest-based ecosystem services, forest ecosystem processes, and their linkages are quantified. To provide context, we first give an overview of common ecological assessment frameworks, including risk, vulnerability, resilience, and indicator-based approaches. Assessments tended to target either ecosystem-level properties thought to be important for ecosystem service sustainability, or else to target specific ecosystem services or stressors. Forest ecosystem-level assessment most often relied on specific indicators for system properties such as integrity or health, but how those properties or their indicators were related to ecosystem services was typically not quantified. Individual ecosystem services were frequently assessed in terms of risk and vulnerability to specific external stressors, but linkages to ecosystem processes, and potential tradeoffs among ecosystem services, were infrequently quantified. Integrated system-level assessment and ecosystem service assessment can improve support for ecosystem management by advancing our understanding of dependencies on the ecosystem processes that are modified through management. Models that evaluate ecosystem services and underlying processes in a systems context offer one approach to do so.
\end{abstract}

Keywords: ecosystem management; ecosystem services; ecological assessment; resilience; regional assessment; vulnerability

\section{Introduction}

Scientists produce regional ecological assessments to supply information about natural resource sustainability in a form that is accessible for policy, planning, and land management applications. Assessment practitioners seek to quantify how ecosystem services (ES) such as the provisioning of clean water, carbon storage, wildlife habitat, harvestable products, and outdoor recreation are supported by ecosystems and how they are compromised by stressors such as overuse, land use change, climate change, and invasive species. Assessments may have very large scale and scope, geared mainly towards informing policy-examples include the Intergovernmental Science-Policy Platform on Biodiversity and Ecosystem Services regional assessment report for the Americas [1] and the US Forest Service Resources Planning Act Assessment [2]. More limited assessments are common for specific regions, undertaken by a variety of organizations and typically geared towards informing land management planning and decision-making [3]. We refer to these as regional ecological assessments-assessments of this kind often provide the best available overview of ecological conditions, environmental stressors, and resource sustainability for a given region. 
Regional ecological assessment has increasingly made use of the ES concept, wherein ecosystem functions are quantified in terms of benefits to people [4]. This perspective has clear relevance for assessing sustainability and informing ecosystem management, but it also raises practical questions about how ecological assessment is performed. A central issue is the ecological level of organization at which assessment is focused. The ES concept encourages a focus on narrow ecosystem components and functions that produce particular benefits such as harvested species or drinking water, but at the same time, it emphasizes societal dependence on whole ecosystems to supply a wide variety of ES, not all of which are readily quantified [5-7]. Assessment may therefore be focused on ecosystem components such as a single tree species, processes with broader implications such as ground water filtration, or at the level of whole ecosystems or landscapes.

A primary objective for regional ecological assessment is to meet information needs for ecosystem management, and land managers using ecosystem management approaches are among the most important stakeholders for ecological assessments. Ecosystem management emphasizes conserving broad ecosystem processes such as nutrient cycling, biomass production, and natural disturbance regimes, and espouses sustainability as a system-level, rather than a resource-level, objective [8-10]. In practice, land managers contend with whole ecosystems as well as individual, high-priority ES, resources, or species in a single decision space for the same landscapes-a reality recognized in ecosystem management. For example, in fire-adapted ecosystems, the broad impacts of prescribed fire on system structure, function, and composition are of central concern, while the need to improve habitats for specific species through prescribed burning may also influence decisions [11].

Ecosystem management stresses the need to understand particular resources and broader ecosystem properties not separately but integratively, recognizing that these linkages-how valued resources are generated and maintained by underlying system processes-are of fundamental management concern. Not coincidentally, understanding how various ES are sustained by ecosystem processes within a whole system context has been considered a priority for ES science [12,13]. In practice, quantifying these functional relationships has lagged behind the basic measuring and mapping of individual ES provisioning, because mapping may be perceived as more immediately relevant for resource protection or because it may be more achievable with less intensive research $[7,14,15]$.

Our goals were (1) to examine how regional ecological assessments have approached the quantification of ES, their stressors, and the ecosystems that provide ES, and (2) to explore how these approaches might be advanced to improve the relevance of regional ecological assessment for informing ecosystem management. First, we provide context by reviewing dominant assessment frameworks-risk, vulnerability, and resilience assessment, as well as indicator-based approaches-highlighting their relevance for ES and their association with different levels of analysis. Specifically, we distinguish between ES-focused and ecosystem-focused analysis. Next, to understand the practice of regional ecological assessment in this context, we reviewed assessment documents for the Appalachian Landscape Conservation Cooperative (ALCC) region. The ALCC was a regional conservation partnership, active from 2010 through 2018 across an area including parts of 15 states in the eastern United States [16]. The assessments we included were not specific to the partnership, but were relevant for the region. We summarized the range of forest-based ES, ecosystem properties, and stressors given attention in assessments, and characterized the quantitative approaches taken to their analysis.

Last, in light of our review, we discuss differences that we found between assessment theory and practice, and ways that assessment practice can be advanced. We suggest that integrative assessment approaches can inform the management of complex forest landscapes that support a variety of ES. In particular, we overview systems-based approaches that can help to connect ES outputs to the ecosystem processes that are the main target of ecosystem management.

Our review was limited in several ways. We took a case study approach, limited to the ALCC region, and we focused on analyses of forest ecosystems, the dominant natural 
vegetation in the region. We focused on biophysical assessment of these systems, i.e., quantifying the condition and functioning of ecosystems and landscapes that provide ES. While assessing ES may be considered an inherently social-ecological enterprise because the focus is on the societal benefits and uses of ecosystems, biophysical assessment is a crucial element of this enterprise, and it is the element most often targeted in ecological assessment $[7,15,17]$. Where appropriate, we illustrate connections with social-ecological analysis and situate findings within this context.

\section{Ecological Assessment Frameworks}

Distinctions among common assessment frameworks relate closely to choices about assessing ES and their stressors either individually or synthetically at broader ecosystem levels (Figure 1) [5]. An exhaustive review of assessment theory is beyond our scope, but to provide context for our case study, we describe risk, vulnerability, resilience, and indicator-based frameworks and point out advantages and challenges in implementing them for ES assessment.

Assessment

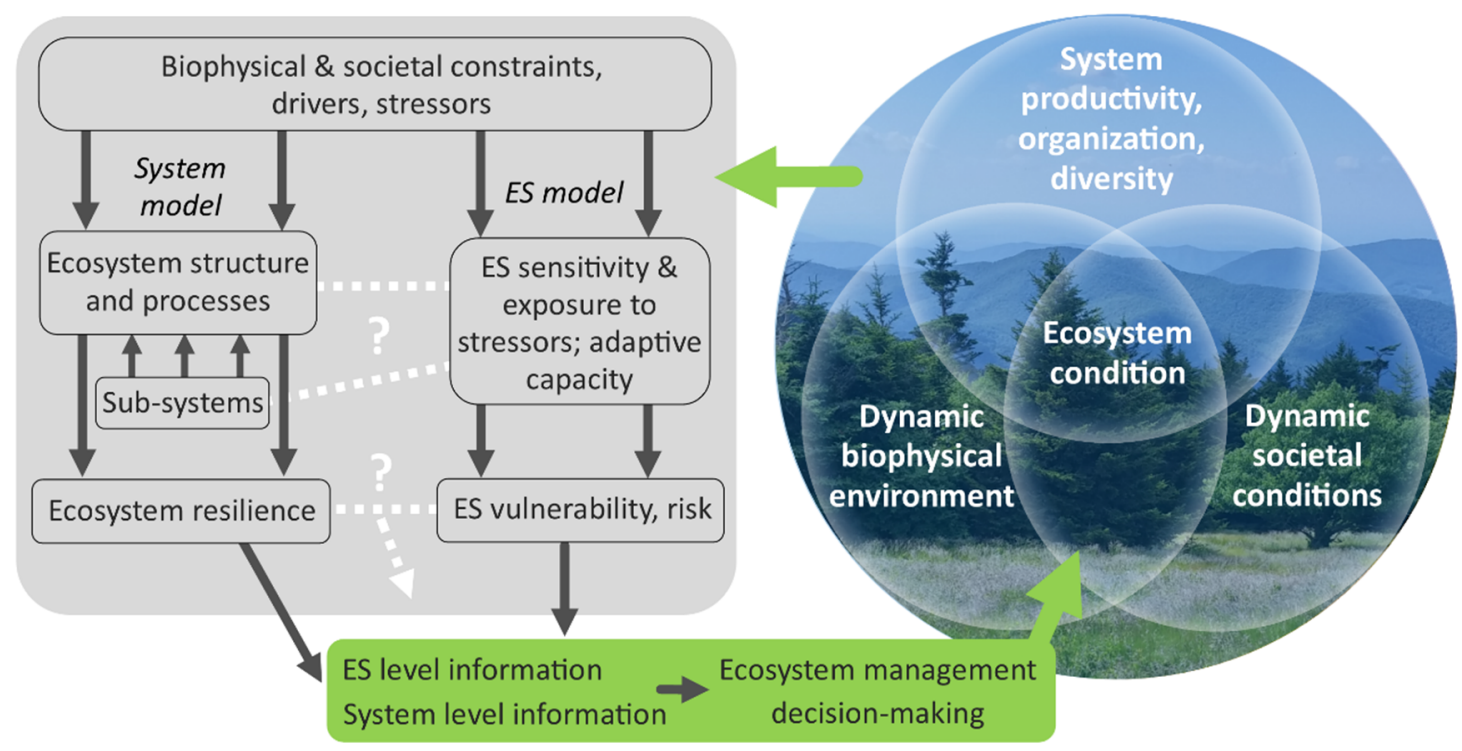

Figure 1. Representation of ecosystems and ecosystem services (ES) in ecological assessment frameworks. The capacities of ecosystems to support ES vary in response to environmental and societal conditions. These dynamics are represented in different ways by system-oriented assessment models and ES-oriented models. Assessments that quantify ecological effects, feedbacks, and other functional linkages between these different levels of organization, treating ES as integral system components, are uncommon (suggested by dashed white lines). Integrative assessments can aid ecosystem management by providing knowledge about dependencies in the ways various system processes and ES respond to environmental change and management actions.

\subsection{Assessing Ecosystem Services Individually}

Most efforts to incorporate ES in ecological assessment use risk or vulnerability frameworks, although risk or vulnerability language is not always used [18]. Risk and vulnerability are both measures of the susceptibility of a system, resource, process, or species to harm due to exposure to environmental stressors [19-21]. Risk and vulnerability assessment both accommodate the estimation of costs potentially resulting from this susceptibility, e.g., the likelihood of ES loss if no action is taken. This involves building conceptual and quantitative models to anticipate outcomes based on the exposure and sensitivity of ES to stressors (Figure 1). Sensitivity indicates the expected response to a given level of exposure [22]. Risk and vulnerability are chiefly distinguished by the former's emphasis on estimating costs and benefits of likely outcomes to aid decision- 
making (i.e., risk analysis), and the latter's emphasis on adaptive capacity, i.e., dynamic responses to stressors that reduce sensitivity or otherwise help to prevent loss [20,23].

Quantifying sensitivity and exposure to stressors can yield a mechanistic understanding of ES degradation with specific management implications for reducing stress, and predictive results mapped across landscapes can be integrated into planning efforts [24-26]. Active areas for ES risk and vulnerability model advancement include the development of process-based, spatiotemporal models; linking the production of ES with their flows to people; and accounting for adaptive capacities and feedbacks [14,27-29].

Risk and vulnerability frameworks are widely embraced for ES assessment, generally implemented at individual ES levels of analysis. This approach allows change in the provisioning of a given ES to be predicted, given the dynamics of various stressors, landscape conditions, and management activities $[14,30,31]$. Risk and vulnerability can also be framed as system-level properties, but, in practice, they are usually descriptors of the component(s) of an ecosystem or social-ecological system thought to be particularly susceptible to stress or having the highest management concern [22,32].

Challenges exist in linking such assessments to ecosystem management, an approach which assumes that ES arise from core ecosystem processes and are not independent from those processes or from one another $[7,9,10]$. One approach to leverage systemlevel information is to compile multiple independent vulnerability assessments for a group of complementary ES or collective 'bundles' of ES that occur together in the same landscapes [32-34]. However, decision support needs for ecosystem management are likely to require explicit consideration of interdependencies, including relationships to ecosystem processes. For example, an integrated framework may allow explicit analysis of tradeoffs among different ES gained or lost under management scenarios that affect whole systems and broad system processes [22,30].

\subsection{Assessing Ecosystem Services at the System Level}

Most assessments which characterize ES sustainability at the ecosystem level, or strive to be synthetic in the sense that they account for a spectrum of ES, use an indicator approach $[35,36]$. This typically involves indices that combine several measurable system traits, which are either demonstrated or assumed to collectively indicate an ecosystem property, such as integrity, health, or resilience $[37,38]$. Such indices have been compiled from measurements of biomass, species richness and composition, land use, land cover, habitat connectivity, topography, climate, geology, and other features-methods for combining and weighting different measurements into an index are highly variable among assessments [39-44].

Indicators provide a practical way to assess elusive system properties, while their utility depends on the reliability of the relationship between indicators and the properties of interest. This in turn depends on properties such as ecosystem health and integrity having clear operational definitions, credibly linked to observable characteristics [45]. An additional challenge involves uncertainty in the relationship between indicators and ES themselves-particularly when several indicator metrics are summarized as a single index [37,44,46]. Recommendations for enhancing indicator approaches have emphasized measuring processes and causal linkages among system components rather than isolated traits or static resource stocks, and explicitly defining any system-level endpoints such as health or integrity $[38,44,47,48]$.

Resilience theory provides an alternative framework, rooted in systems ecology, that favors a system-level perspective and emphasizes quantifying ecosystem processes that underlie multiple ES [49,50]. In a systems framework, models for the functional relationships among internal system components as well as external influences are the basis for estimating system-level resilience (Figure 1). Recent definitions of resilience describe a multi-faceted property of systems wherein both an ability to recover from disturbance or stress and an adaptive capacity for more fundamental transformation contribute to the maintenance and renewal of system functioning [51-53]. This view was first applied 
to social-ecological systems, but it can also describe the capacity of ecosystems to cope with multiple interacting stressors and to sustain fundamental ecological processes under environmental change $[6,53,54]$.

For example, a forest's species composition and structure change over time in response to multiple stressors, including fire, insect pathogens, and timber harvest. A resilient forest under these dynamics continues to develop and retains the adaptive capacity to provide a variety of ES, although specific ES may be diminished or enhanced over time [50,51]. This implies that the ES provided by future landscapes cannot be fully anticipated given uncertain societal and ecological change. Managing for resilience therefore entails sustaining robust ecosystem processes and guiding system change to support dynamic capacity for ES under a variety of possible future conditions-an approach with clear affinities to ecosystem management principles.

However, challenges exist for assessing ecosystem resilience with respect to ES. Doing so entails accounting for how system structures and dynamics respond to environmental change and stress, and how resulting pathways of system change enhance or compromise different ES $[50,55,56]$. Monitoring ecosystems in sufficient detail to quantify these complex dynamics at the spatial and temporal scales relevant to ecosystem managementusually, large landscape scales and decadal timescales-is daunting [46]. Further, communicating conceptually unfamiliar system analyses to stakeholders and decision-makers can be difficult, although this is improved when connections to ES-level concerns are explicit $[15,57,58]$.

\section{Appalachian Regional Ecological Assessment}

\subsection{Methods: Reviewing Assessments}

The Appalachian region, with the Appalachian Mountains as its defining feature, includes a large but widely dispersed human population, high biological diversity on private and public lands, an extensive system of protected areas, and intensive natural resource extraction particularly in the energy sector-resulting in a complex intermixing of landscape types, uses, and values. We sought to examine how ecological assessments relevant for this region have quantified and evaluated $E S$, focusing on whether and how functional relationships between ES and their stressors, or ecosystems and their stressors, were quantified, as well as whether and how functional relationships between ES and ecosystem processes, or ecosystem-level properties represented by indicators, were quantified.

We searched for regional or national assessments that quantified the capacities of Appalachian forest ecosystems to supply ES or comparable natural resources, and/or regionally important stressors on those capacities. We included assessments covering the ALCC region or a major subregion (one or more states). Assessment documents ranged from online-only web pages to 'gray' literature not readily discoverable online. Our search therefore included bibliographic searches in the broader peer-reviewed literature, online searches, and queries made to scientists at agencies and NGOs with a presence in the study region.

Summarizing how ES have been analyzed required a way to identify and classify ES, a process that involves subjective judgement, whether classifying by ecological process, human use, or other criteria [5,59]. Terms encountered in assessments, such as 'natural resources', 'natural assets', or ecosystem 'goods and services', frequently referred to ecological outputs comparable to ES. Rather than attempting to match these to technical groupings such as provisioning, supporting, regulating, and cultural ES [12], we identified frequently recurring categories in the assessments themselves. These usually corresponded to ecological outputs whose relevance to human well-being is clear without technical explanation [59], such as water quality or nontimber forest products.

We first synthesized the broad findings of assessments with regard to ES sustainability, documenting analyses of individual ES and stressors, as well as landscape- or ecosystemlevel properties that were connected either implicitly or explicitly to ES. We then examined assessment analytical approaches. Assessment documents typically included multiple 
separate analyses, which we evaluated individually. We asked if relationships between ES and stressors, or ecosystems and stressors, were modeled analytically-e.g., using sensitivity and exposure models or ecological production functions [14,20]. For forest ecosystem-level properties, we asked whether these properties were examined using indicator or systemic approaches, and whether they were linked to ES explicitly (i.e., quantitatively). In all cases, we asked whether analysis was spatially explicit at the county level or finer.

\subsection{Findings: Diverse Services and Stressors, Limited Assessment Tools}

Appalachian assessments (Appendix A) quantified the biophysical provisioning of a variety of ES, corresponding to diverse and sometimes competing land and water uses. We identified 11 ES categories and eight stressor categories (Figure 2). We further grouped these into four and five categories, respectively, for a broad synthesis of assessment findings (Appendix B). Services included basic resources such as clean drinking water, bases of local economies such as nature-based tourism and harvested forest products, and forest carbon storage as a climate regulating service. They also included less tangible benefits such as rural landscape values-the sense of place that rural communities derive from landscapes dominated by natural features-and aesthetic appreciation of landscapes by visitors (Figure 3). Regionally important stressors included aspects of land use intensification, extensification, and landscape fragmentation-particularly including urbanization, energy resource extraction (e.g., surface mining), and infrastructure associated with energy development (e.g., hydraulic fracturing). Stressors also included forest pathogens, invasive species, and climate change (Figure 2, Appendix B). Many ES, landscape, ecosystem, and stressor variables were represented spatially, with approximately half of analyses including some form of spatially explicit evaluation and map product (Figures 2 and 4).

(a) Ecosystem conditions Rural landscape values

(b)

Timber products
Hydrological flow

Water quality

Carbon storage

Outdoor recreation Wildlife habitat Soils Nontimber products Human health

(c)



Figure 2. Categories of (a) ecosystem-level properties, (b) ecosystem services (ES), and (c) stressors quantified in 22 ecological assessment documents (Appendix A) that covered the Appalachian region or a significant subregion or state, and that focused on forest-based ES or resources. 'Ecosystem conditions' is used here to include ecosystem-level or forest-level properties encountered in assessment documents, including integrity, condition, health, and resilience. Specific definitions for these properties varied among documents. Total = percent of assessments in which the category was addressed quantitatively; Spatial = percent in which the category was quantified spatially at the county level or finer; ES-stressor model = percent in which a quantitative relationship expressed the effect of one or more stressor on an ES or system-level property. 


\section{Timber products}

Hardwood production has been a key economic activity across the Appalachians, supporting rural livelihoods and supplying products at regional to global levels. Sustainable markets create an incentive to keep land forested, and working forests can support many other ES if appropriately managed. Timber stocks and production have been stable in recent decades, but are at risk of decline.

\section{Nontimber forest products}

Many products such as wild herbs are harvested in the region, and hunting and fishing are important recreational activities. Sustaining cultural and economic values associated with forest products can be compromised by overexploitation, as can occur in poorly regulated places and near population centers.

\section{Water, hydrology, and soils}

The Appalachians provide abundant clean water to populations within and beyond the region. Forests are important for drinking water, water-based recreation, and aquatic habitat quality. Forest conditions influence streamflows, which in turn affect flood risk, recreation and tourism, and habitat quality. Forest soils support many ES including clean water, streamflow regulation, carbon storage, and forest products. Forest and wetland management and restoration can improve soils, water quality, and streamflow regulation.
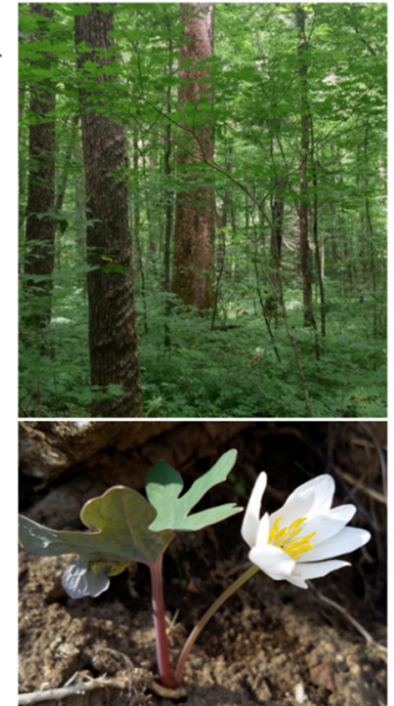

Rural landscape values

Many of Appalachia's inhabitants value the sense of place associated with rural, largely forested places. They may also value the economic activity that development and industry bring. When these values compete, there may be an expectation that the quality of rural life need not be eroded as landscapes change. Development consistent with this expectation is challenging but possible.

\section{Outdoor recreation}

An abundance of natural areas, streams and rivers, and public lands make the Appalachians a prime destination for nature-based recreation and tourism. Associated economic activity creates incentives for forest and freshwater management that enhances a wide variety of compatible ES, but poorly managed recreation can also erode ES.

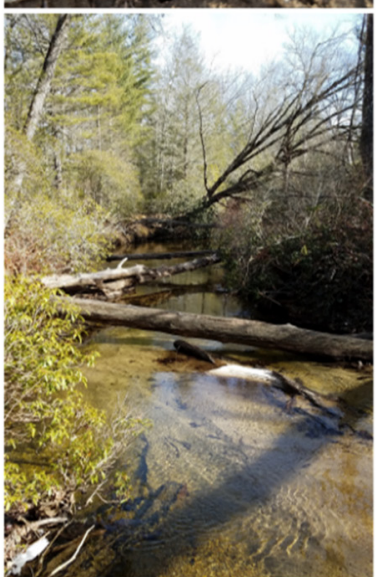

\section{Forest carbon}

Carbon sequestration and storage in forest plants and soils are components of climate change mitigation provided by Appalachian forests. Net carbon storage has increased over recent decades with growing forest age and extent. Rates of increase are declining, but old forests store massive amounts of carbon. Preventing these forests from becoming net carbon sources may involve urban development policy, restoration efforts on mined sites, and changes in energy markets and forest product markets.

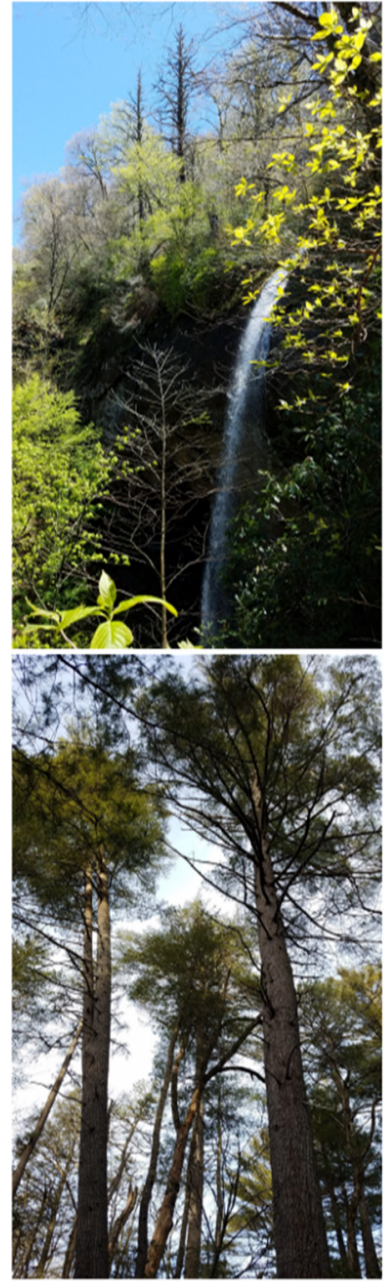

Figure 3. Ecosystem services provided by forested landscapes are abundant and diverse. Principles of ecosystem management highlight the importance of understanding these ES as integral components of entire ecosystems with dependencies on ecological processes at multiple scales and system organizational levels. Examples of ES described here were among those most frequently included in ecological assessment documents for the Appalachian region; statements regarding sustainability and management were synthesized from these documents (Appendices A and B-the ES shown here are further grouped into four categories in Appendix B). The flowering plant pictured at left is Bloodroot (Sanguinaria canadensis), a species harvested for use in the medicinal trade. Photos by the first author in western North Carolina. 


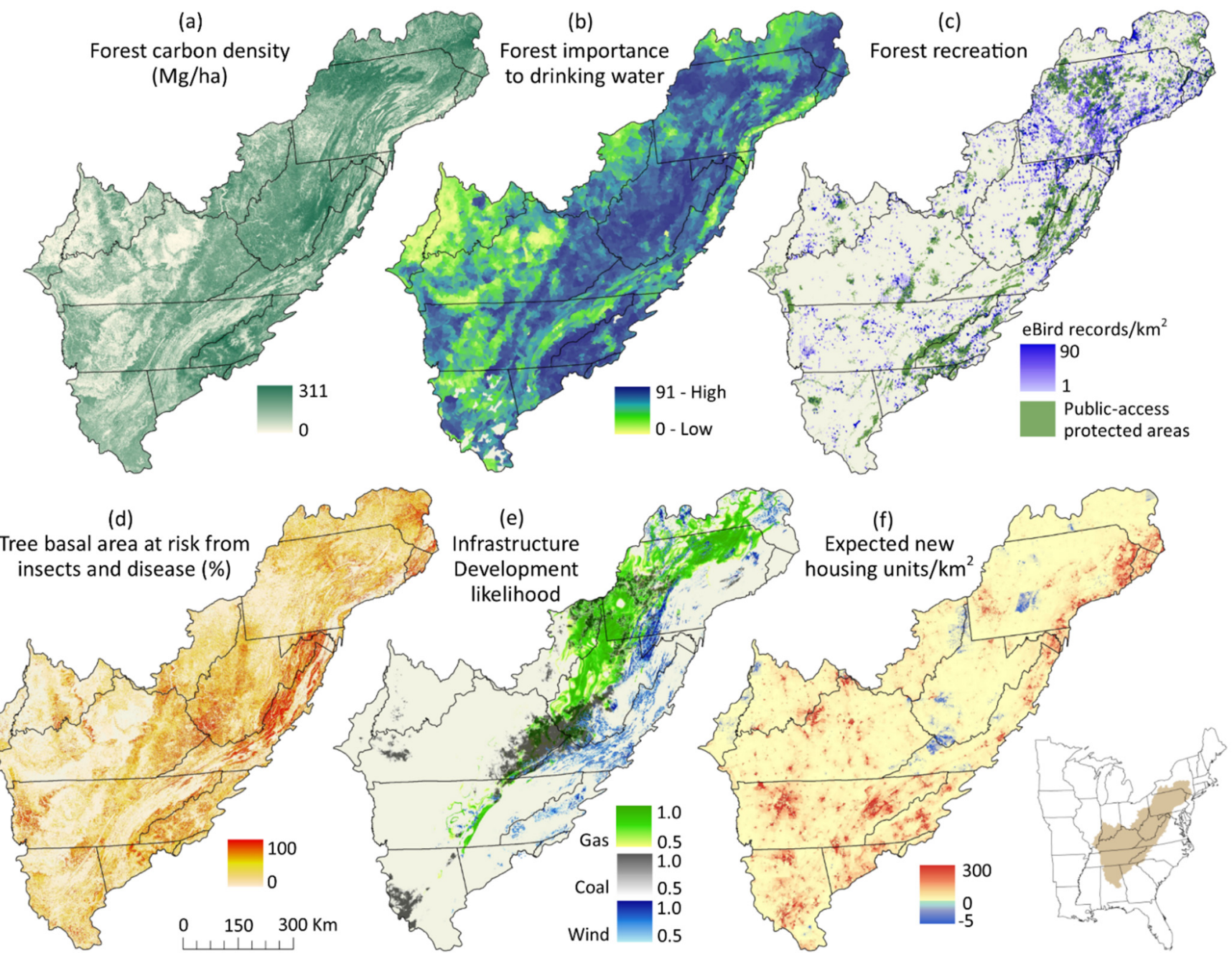

Figure 4. Examples of ecosystem service $(\mathbf{a}-\mathbf{c})$ and stressor $(\mathbf{d}-\mathbf{f})$ distributions across the ALCC region. Inset shows the ALCC location in the eastern United States. (a) Total forest stored carbon density (Mg/ha), 2000-2009 [60]. (b) Importance of forests for drinking water supply [61]. (c) Forest recreational uses: protected natural areas with public access, and density of citizen science observations of a common forest bird group (Vireo spp.) from 2003 to 2012 (observations / km²) [62,63]. (d) Expected composite risk of forest tree mortality from insects and disease, 2013-2027 (\% of basal area) [64]. (e) Expected likelihood of infrastructure build-out for gas, coal, or wind energy extraction by $2035[65,66]$. (f) Expected change in housing density, 2010-2030 (units $/ \mathrm{km}^{2}$ ) [67].

Analyses of system-level properties, described in assessment documents as the condition, integrity, health, or resilience of ecosystems, landscapes, or forests, occurred in around half of the assessment documents, but comprised a minority of analyses in any document (Figure 2). We included rural landscape values (Figure 3) as system-level properties when assessed at synthetic landscape levels rather than as a specific resource. In all cases, systemlevel analyses used indicator variables or composite indices to represent system properties. For example, low forest fragmentation was used in several analyses to indicate high system integrity [68].

Approximately half of quantitative assessments did not include any analysis of a functional or predictive relationship between stressors and ES, ecosystems, or ecosystem processes, beyond comparing their spatial distributions (Figure 2). In such cases, there was no explicit model for these relationships, such as an ecological production function or estimation of sensitivity, effect, or adaptive capacity. Those cases that did include some quantified or modeled stressor effect were dominated by assessments of individual ES, rather than ecosystems or system-level properties. 


\section{Discussion: Towards Integrative Assessment}

Our case study review indicated that various analytical approaches have been applied unevenly across ALCC-relevant assessments. This may be due in part to uneven awareness of emerging science, but it may also reflect judgements of practitioners concerning the usability, fitness-to-purpose, or relevance of available frameworks and analytical tools. Our findings emphasize a need to better integrate between ecosystem and ES organizational levels, guided in part by theory linking ES outputs to ecosystem processes. We further suggest that adopting ES-ecosystem integrative approaches will facilitate science-management integration, by helping to clarify how ecosystem management decisions and activities can support ES sustainability.

\subsection{Connecting Ecosystem Services to Ecosystems}

In the Appalachian assessments that we reviewed, ecosystem-level analyses-all based on indicator or index approaches-were usually included side by side with ESlevel analyses, often justified by implicit links between ES and ecosystem-level structure and process. This suggests that assessment practitioners recognize the importance of functional relationships across these different levels of organization. However, these links were seldom analyzed explicitly. For example, an assessment of forest resources for the Appalachian Regional Commission [69] included spatially explicit market and non-market valuation of forest-based ES including timber harvest, carbon stocks, wildlife habitat, recreational use, and watershed services. Separately, broader forest condition was quantified as a compilation of indicator metrics including tree growth and mortality rates, invasive species occurrence, risk of land use change and forest pathogens, and other disturbances. While these separate analyses have value in their own right, a premise of the assessment was that forests in good condition (as defined and measured therein) support greater ES value-but this relationship was not quantified or tested.

Quantifying functional relationships between ES and underlying ecosystem processes was rare in assessments, but this approach can improve analytical linkages among system properties such as resilience, vulnerabilities of specific ES, and risks associated with specific stressors. These relationships may not be straightforward-ecosystem capacities to provide particular ES are likely to be associated strongly with some system processes or components and weakly with others $[14,17]$. Stressors such as forest pathogens and fire likewise have variable impacts on different system processes and components, with variable consequences for different ES [50,70]. A forest's resilience to climate change, for example, may not directly predict an ES such as carbon storage, but this system's resilience and carbon storage capacity may shape one another in important ways.

No assessment that we reviewed used a system approach-e.g., based in systems theory or a process-oriented analysis-to quantify system-level properties, but we suggest that such approaches can advance understandings of ES-ecosystem linkages. For example, system properties such as resilience arise in system models from ecosystem component structures and the processes relating them to one another. Outputs such as quantified complexities, uncertainties, and organization of systems may be useful inputs in models for individual ES, where ES-stressor sensitivities are modulated by system properties [71]. An alternative systems approach to quantifying these relationships is to model the pathways through which multiple stressors influence multiple ecosystem components and processes, impacting multiple ES outputs (with possible interactions and feedbacks). This approach essentially incorporates ES as system components, processes, or outputs $[5,7,54,72]$. While beyond the scope of this review, system approaches have also been expanded to encompass social-ecological systems hierarchically. This can advance integration of the full ES cascade, which links ecological processes with flows of ES to society, in a systems framework [72].

System analyses and models take a variety of forms, which have not been fully explored in the context of assessment, but which should be useful. Assessment from a systems perspective contrasts with most indicator-based approaches in that system-level properties emerge from the dynamic functional relationships among system components, and so are 
intrinsically process-based. For example, ecological network approaches have been used to examine how aspects of system complexity influence process stability in changing environments [73]. Network analysis can help to identify pathways and thresholds whereby stressors impact ecosystem components or push ecosystems outside their historical stability domains $[56,70,73]$. Information-theoretic measures, especially system entropy, have been used to quantify multiple dimensions of complexity linked to resilience observed in food webs, landscape structure and dynamics, and ecosystem processes [74-76]. Informationtheoretic frameworks characterizing ecosystem development have been adapted to study ecological resilience and sustainability [55,77].

Identifying appropriate system structures and dynamics for measurement depends not only on the ES of interest, but also on the scales at which systems are delineated. This implies that properties quantified by resulting system models (e.g., complexity, adaptive capacity, resilience) are specific to these scales and ES scopes. Choices of scale for assessment connecting these system properties to ES include the scales at which people are strongly connected to ecosystems through interactions such as land and resource use and management, conservation, and recreation - the interactions around which ES are normally defined $[7,53,78]$. This suggests relatively broad landscape scales, and in the assessments that we reviewed, the frequent inclusion of spatially explicit analysis at broad landscape scales (Figure 4) also suggests that this general scale domain is of particular relevance.

These broad scales further suggest that system-level assessment requires a way to monitor ecosystem and landscape structures, processes, and change across large areas. Large-area monitoring should also maintain a capacity for ecologically nuanced evaluation of change at spatiotemporal scales commensurate with ES dynamics and management domains, a major challenge [38]. This is likely to rely in part on remote sensing technologies [79-81]. Historically, remote sensing-based change estimates have been limited to typologically and temporally coarse measures such as gross forest loss and gain at five- to ten-year intervals [14,27]. Richer characterization of vegetation productivity, disturbance, structure, phenology (the timing of biological changes), and other informative measures using remotely sensed data with frequent re-measurement intervals enhances ecosystem change modeling, but requires greater analytical investment $[82,83]$. Advances in this field are beyond the scope of this review, but we suggest that increasingly nuanced remote sensing-based observation of vegetation and land surface character, organization, and dynamics will continue to advance efforts to quantify ecosystem-level properties relevant for ES across large landscapes.

\subsection{Connecting ES Science and Ecosystem Management}

Ecosystem management strategies are often characterized by efforts to minimize risk while optimizing outcomes across multiple resources. When ES are analyzed individually, managers have the task of synthesizing varied assessments to evaluate management options (Figure 1), with little information about tradeoffs and interactions. Integrative assessment frameworks taking advantage of system and network analyses can help to cope with this complexity and to address ES and ecosystems together in an ecosystem management context.

In the assessments that we reviewed, discussions of forest ecosystem management activities such as prescribed burning, invasive species removal, and forest stand thinning were frequently framed around promoting system-level ecological properties such as resilience or ecological integrity. The importance of system-level properties was typically expressed in terms of their role in mitigating stressor impacts on a wide variety of specific ES. Often, these relationships with specific resources and stressors help to give definition to holistic ecosystem management goals which may otherwise appear vague $[6,9]$.

Indeed, ecosystem management decisions are complex when a wide array of ES is at stake. Risk and vulnerability assessments for individual ES can be well-suited to inform single issue-focused management, but more complex decision-making involving multiple criteria can benefit from quantifying multiple ES as ecologically (or socio-ecologically) 
linked phenomena [7,14,22]. For example, the Southern Forest Futures Project [84] undertook a variety of independent assessments of regionally important natural resources and ES, identified through stakeholder workshops. They used empirical models as well as forecasting under varied economic and ecological scenarios to provide context for future management options for particular ES. Continued work in this area could address how management options designed to promote one ES are likely to affect other ES, and how ecosystem management to promote system-level properties is likely to affect various ES.

Moreover, integrating management activities as drivers in system models provides a tool for adaptive management [3,10]. Management strategies may shift depending on continuous learning about the diverse responses of various ES to system change, including past management interventions. This is only possible when periodic assessment is geared towards detecting consequential system change, which implies that monitoring tools and system models with the appropriate sensitivities should be carefully matched to adaptive management goals [38,85].

Finally, analytical innovations that improve the management relevance of assessments are likely to succeed when they occur in the context of science-management engagement $[15,86,87]$. System models whose components are relevant and scaled to regional management priorities are unlikely to be arrived at without engagement from managers, and complex models are unlikely to be adopted as ecosystem management tools without engagement from researchers. The Landscape Conservation Cooperatives, including the ALCC, are an example of regional partnerships intended to create such dialogue [88]. The most significant achievement of the LCC Network may have been the development of research-management communities working across large landscapes and across institutional boundaries. Capacity for innovation in integrative assessment that is responsive to the needs of ecosystem management depends in part on the continued development of such communities.

\section{Conclusions}

We documented important differences between ES assessment theory and practice in our review of Appalachian ecological assessments. These differences suggest challenges and a future agenda for advancing regional ecological assessment for ecosystem management decision support. We found that the analysis of forest ecosystems and landscapes as complex, open systems affected by stressors and having functional links to all ES is well theorized, but also methodologically challenging and infrequently employed in regional ecological assessments. Linkages between ES and ecosystem processes, or indeed even explicit models for relationships among ES and stressors, were less common in assessments than expected, given their importance in risk and vulnerability analysis. Improving these analytical linkages will improve operational linkages between ecological assessment and ecosystem management. The relevance and impact of assessment also depends on science and management communities of practice working together to advance how ES sustainability is conceptualized and quantified. This will lead to an improved understanding of the capacity of ecosystems to adapt to novel conditions such as modern land use and climate change while continuing to provide valued benefits.

Author Contributions: Conceptualization, L.Y.P. and D.C.L.; methodology, investigation, and original draft preparation, L.Y.P.; review and editing, D.C.L. and L.Y.P.; project administration and funding acquisition, D.C.L. All authors have read and agreed to the published version of the manuscript.

Funding: This research was funded in part through an Interagency Agreement between the USDA Forest Service and the United States Fish \& Wildlife Service, agreement number 14-IA-11330110-002.

Acknowledgments: Jean Brennan was instrumental in developing goals and direction for the synthesis of Appalachian ecological assessments. Anonymous reviewers provided useful comments on a previous version of the manuscript.

Conflicts of Interest: The authors declare no conflict of interest. 


\section{Appendix A}

Regional environmental assessments included in our review for the Appalachian region.

Table A1. Regional and national assessments with direct relevance to the provisioning of forest-based ecosystem services and their stressors, even if explicit ecosystem service language was not used in assessment documents. Assessments encompassed either the Appalachian Landscape Conservation Cooperative (ALCC) region, which included significant parts of 15 states in the eastern United States, or at least one state within the ALCC. ${ }^{*}$ Reports were available for 12 (state forest inventories) and 11 (state forest action plans) states partially or wholly in the ALCC region. We selected three representative states within each of these two assessment groups to include in our quantitative review of ecosystem service and stressor analyses (Figure 2). This reduced bias towards the approaches taken in these assessments, which were similar but not identical across states.

\begin{tabular}{|c|c|c|c|c|}
\hline & Assessment Document & Institution/Agency & Regional Coverage & Reference \\
\hline \multirow{10}{*}{  } & $\begin{array}{l}\text { 2013-2027 National Insect and Disease Forest } \\
\text { Risk Assessment }\end{array}$ & USDA Forest Service & United States & [64] \\
\hline & $\begin{array}{l}\text { Assessment of Nontimber Forest Products in } \\
\text { the United States Under Changing Conditions }\end{array}$ & USDA Forest Service & Coterminous US & [89] \\
\hline & $\begin{array}{l}\text { An Ecological Assessment of the US } \\
\text { Mid-Atlantic Region: a Landscape Atlas }\end{array}$ & Environmental Protection Agency & Mid-Atlantic US & [39] \\
\hline & $\begin{array}{c}\text { Environmental Protection Agency's Report on } \\
\text { the Environment }\end{array}$ & Environmental Protection Agency & Coterminous US & {$[90,91]$} \\
\hline & $\begin{array}{l}\text { Forests of the Northern United States (The } \\
\text { Northern Forest Futures Project) }\end{array}$ & USDA Forest Service & Northeastern US & [92] \\
\hline & Forests to Faucets & USDA Forest Service & Coterminous US & [61] \\
\hline & $\begin{array}{c}\text { Future of America's Forest and Rangelands: } \\
\text { Forest Service Resources Planning } \\
\text { Act Assessment }\end{array}$ & USDA Forest Service & United States & {$[2,93]$} \\
\hline & $\begin{array}{c}\text { National Report on Sustainable Forests } \\
\text { (Montreal Process) }\end{array}$ & USDA Forest Service & United States & [68] \\
\hline & The Southern Forest Futures Project & USDA Forest Service & Southeastern US & {$[84,94]$} \\
\hline & $\begin{array}{l}\text { State forest inventory: Individual reports for } 12 \\
\text { Appalachian states. Pennsylvania, Indiana, and } \\
\text { North Carolina included in quantitative review. * }\end{array}$ & USDA Forest Service & State-level, 12 states & [95-97] \\
\hline 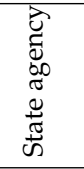 & $\begin{array}{l}\text { State Forest Action Plans: Individual reports } \\
\text { for } 11 \text { Appalachian states. Alabama, Ohio, and } \\
\text { New York included in quantitative review. * }\end{array}$ & State forest resource agencies & State-level, 11 states & [98-100] \\
\hline \multirow[t]{2}{*}{$\begin{array}{l}0 \\
0 \\
Z\end{array}$} & $\begin{array}{c}\text { Assessing Future Energy Development Across } \\
\text { the Appalachian Landscape } \\
\text { Conservation Cooperative }\end{array}$ & The Nature Conservancy & Appalachian region & {$[65,66]$} \\
\hline & Southern Forests for the Future & World Resources Institute & Southeastern US & [101] \\
\hline \multirow{5}{*}{ 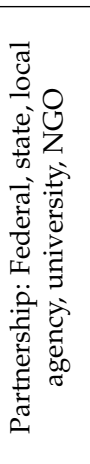 } & $\begin{array}{l}\text { An Assessment of Natural Assets in the } \\
\text { Appalachian Region: Forest Resources }\end{array}$ & Appalachian Regional Commission & Appalachian region & [69] \\
\hline & $\begin{array}{l}\text { An Assessment of Natural Assets in the } \\
\text { Appalachian Region: Water Resources }\end{array}$ & Appalachian Regional Commission & Appalachian region & [102] \\
\hline & $\begin{array}{l}\text { Central Appalachians Forest Ecosystem } \\
\text { Vulnerability Assessment and Synthesis: A } \\
\text { Report from the Central Appalachians Climate } \\
\text { Change Response Framework Project }\end{array}$ & $\begin{array}{l}\text { Northern Institute of Applied } \\
\text { Climate Science/USFS }\end{array}$ & Central Appalachians & [103] \\
\hline & $\begin{array}{c}\text { Central Hardwoods Ecosystem Vulnerability } \\
\text { Assessment and Synthesis: A Report from the } \\
\text { Central Hardwoods Climate Change Response } \\
\text { Framework Project }\end{array}$ & $\begin{array}{l}\text { Northern Institute of Applied } \\
\text { Climate Science/USFS }\end{array}$ & US Central Hardwoods & [104] \\
\hline & The Southern Appalachian Assessment & $\begin{array}{l}\text { Southern Appalachian Man and } \\
\text { the Biosphere }\end{array}$ & Southern Appalachians & [105] \\
\hline
\end{tabular}




\section{Appendix B}

Appalachian forest ecosystem services and large-scale stressors.

Table A2. The broad ES and stressor categories included here are not exhaustive but were represented in multiple regional assessments (Figure 2). The top half of the table intersects ES (columns) with stressors (rows); the bottom half of the table intersects additional ES with the same stressors. References include regional or national ecological assessments with findings specific to the region (Appendix A), supplemented by specific research within the Appalachian region.

\begin{tabular}{|c|c|c|c|}
\hline \multirow[t]{2}{*}{ Stressors } & \multicolumn{2}{|c|}{ Ecosystem Services } & \multirow[t]{2}{*}{ References } \\
\hline & Water Quality, Hydrology, and Soils & Forest Carbon Storage & \\
\hline Urbanization and fragmentation & $\begin{array}{l}\text { Increasing urban land use coupled } \\
\text { with forest and soil loss in landscapes } \\
\text { with varied topography and steep } \\
\text { slopes can exacerbate stream } \\
\text { discharge rates, peak flow, and } \\
\text { velocity. Increasing impervious } \\
\text { surface and forest and soil loss } \\
\text { typically result in reduced surface } \\
\text { water availability for human use, and } \\
\text { can increase stream sediment, } \\
\text { nutrient, and pollutant concentrations. }\end{array}$ & $\begin{array}{l}\text { Forest loss associated with } \\
\text { urbanization results directly in } \\
\text { reduced carbon storage capacity. } \\
\text { These losses, together with similar } \\
\text { effects of surface mining, may outstrip } \\
\text { regional gains from forest growth, } \\
\text { without significant changes in urban } \\
\text { development policy, restoration } \\
\text { efforts, timber markets, and } \\
\text { other factors. }\end{array}$ & {$[2,39,90,92,94,106-113]$} \\
\hline
\end{tabular}

nutrient, and pollutant concentrations.

Increased impervious surface cover and forest loss with gas well development can alter surface hydrology and reduce water availability and quality. Discharge from watersheds with mined sites commonly shows elevated dissolved solids and acidity, impairing aquatic biota. Negative effects can continue long after reclamation. Watersheds with mined land show elevated runoff, potentially elevating downstream flood peaks. Soil loss and compaction from surface mining and some reclamation practices can impede forest regeneration. Impacts on water quality and availability vary sub-regionally, and depend on interactions with population growth and other factors. Mean temperature increases are likely to reduce water availability in some areas, with rural populations more affected than cities due to stronger reliance on ground water. Recent trends of increasing flood and drought frequency will likely continue. Effects of such events on streamflow depend on landscape vegetation composition and structure, soils, and impervious surface cover.

Species invasions and forest pathogen outbreaks can affect hydrology by changing forest vegetation structure and function. For example, widespread tree mortality in the Appalachians due to the invasive Hemlock wooly adelgid (Adelges tsugae) can temporarily increase

Invasive species and forest pathogens stormflow peaks and cause long-term decline in total stream yield. Invasive plants can change soil properties, reduce nutrient and water availability for native plants, and negatively affect soil microbial communities.
Forest losses associated with energy infrastructure development and surface mining are expected to result in reduced forest carbon storage.

While the carbon storage potential of forest restoration on mined sites is high, successful forest restoration practices are not implemented on many to most sites, and some current practices may prevent significant new carbon sequestration. Carbon losses from future surface mining could outstrip regional carbon sequestration gains from existing forests.

\section{Impacts of climate change on forest} carbon storage are likely to vary across landscapes, and interactions with other landscape dynamics add complexity. Rising temperatures can enhance forest growth and carbon storage, but this can be offset by

drought impacts, and both of these effects depend on tree species composition. Changes in fire frequency due to temperature and precipitation changes will also modify carbon storage capacity, especially where wildland fire alters forest structure and cover.

Forest primary productivity can be strongly reduced in the short term after tree pathogen outbreaks, slowing carbon sequestration. A forest stand can switch from carbon sink to source under these conditions, but this can reverse over the long term as productivity recovers. Multiple outbreaks can reduce carbon sequestration and storage at landscape scales, but long-term impacts are not well understood. Increased frequency of extreme heat and drought with climate change increases forest pathogen outbreak likelihood. 
Table A2. Cont.

\begin{tabular}{|c|c|c|}
\hline \multirow[t]{2}{*}{ Stressors } & \multicolumn{2}{|c|}{ Ecosystem Services } \\
\hline & Water Quality, Hydrology, and Soils & Forest Carbon Storage \\
\hline Wildland fire & $\begin{array}{l}\text { Intense wildland fires can increase } \\
\text { streamflow, soil erosion, and stream } \\
\text { sediment loads and alter soil and } \\
\text { water chemistry in the short term. } \\
\text { Appalachian forests have not shown } \\
\text { large impacts of this kind, with } \\
\text { impacts typically followed by rapid } \\
\text { recovery. Impacts are more likely for } \\
\text { intense fires after fuel buildup than for } \\
\text { low-intensity, frequent-interval fire. } \\
\text { Thus, fire suppression can increase } \\
\text { likelihood of fire with }\end{array}$ & $\begin{array}{l}\text { Wildland fire releases carbon dioxide } \\
\text { into the atmosphere, while forest } \\
\text { regrowth after fire captures and stores } \\
\text { carbon over longer time scales. Thus, } \\
\text { fire is one driver of forest carbon } \\
\text { cycling. The overall contribution of } \\
\text { fire regimes to long-term forest carbon } \\
\text { balances is not well understood in } \\
\text { eastern upland forests where fire is } \\
\text { relatively infrequent. }\end{array}$ \\
\hline
\end{tabular}
negative impacts.

\begin{tabular}{cc}
\hline Stressors & Ecosystem \\
\hline & $\begin{array}{c}\text { Timber and nontimber } \\
\text { forest products }\end{array}$ \\
\hline
\end{tabular}

Urbanization and associated population increase, more pronounced in the southern than the northern Appalachians in recent decades, reduce the land area

Urbanization and fragmentation available to support working forests, and alter the dynamics of nontimber forest product harvest, fishing, and hunting in nearby forests. Absence of fish from degraded streams can cause loss of fishing opportunities.

Surface mining - the largest driver of land cover change in the central Appalachian coalfield

region-reduces land area available to support working forests. Loss of timber-related economic activity can Energy development result, particularly since some common reclamation efforts can impede forest recovery. At regional scales, timber stocks and production have remained fairly stable in recent decades, but declines may be experienced over the long term.

Suitable habitat for harvested species may undergo geographic shifts. At the local level, expected declines in economically important species may not be fully compensated by increases in other harvested species. Climate change may interact locally with

Climate change harvest pressure to increase declines, a risk posing special concern for many nontimber forest products that are not well monitored or regulated.

Forest tree pathogen outbreaks are one of the most important risk factors for harvested species. Associated changes in forest structure and composition can also reduce habitat quality for nontimber species such as harvested understory herbs. Invasive, non-native plants can reduce regeneration and productivity of economically valuable species.

Impacts on harvested species can be exacerbated by facilitators of pathogen outbreaks or invasions including climate change, forest fragmentation, and fire.

\section{vices}

Outdoor recreation and rural landscape values

Urbanization and low-density

development can negatively impact the sense of place of rural

Appalachian communities in forestand agriculture-dominated

landscapes. As rural landscapes and water supplies are converted to more intensive uses, outdoor recreation

opportunities are expected to decline, even while population growth and urbanization place increased demand on nearby recreation sites.

Infrastructure and forest

fragmentation associated with gas wells, wind turbines, and surface mining will continue to impact central Appalachian landscapes. Associated forest loss, stream degradation, and

biotic and aesthetic losses impact natural landscape character. Stream degradation and toxic dissolved solids in watersheds with surface mines are associated with lost fishing

opportunity and reduced game fish abundance, fish biomass, and species diversity.

Climate change can impact sense of place and quality of life when rural economic activities and natural landscape character are affected.

Broad ecological changes including endangerment of some unique Appalachian ecosystems can affect tourism, recreation, and long-term patterns of rural migration, as visitors and new residents seek out particular conditions.

[2,111,130,135-137] References

References

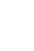


Table A2. Cont.

\begin{tabular}{|c|c|c|c|}
\hline \multirow[t]{2}{*}{ Stressors } & \multicolumn{2}{|c|}{ Ecosystem services } & References \\
\hline & $\begin{array}{l}\text { Timber and nontimber } \\
\text { forest products }\end{array}$ & $\begin{array}{l}\text { Outdoor recreation and rural } \\
\text { landscape values }\end{array}$ & \\
\hline Wildland fire & $\begin{array}{l}\text { Wildland fire in eastern forests does } \\
\text { not typically have strong negative } \\
\text { impacts on timber productivity or } \\
\text { quality. Historically, fire has helped } \\
\text { maintain commercially valuable } \\
\text { Appalachian forest types, including } \\
\text { upland hardwoods. Fire suppression } \\
\text { has resulted in declines of important } \\
\text { species such as oaks (Quercus spp.), } \\
\text { replaced by faster-growing species. } \\
\text { Prescribed fire can help maintain } \\
\text { upland fire-associated ecosystems that } \\
\text { sustain harvested species. }\end{array}$ & $\begin{array}{l}\text { People living near lands affected by } \\
\text { uncontrolled fire may experience risk } \\
\text { to lives and property, and health and } \\
\text { safety risks from smoke and ash. } \\
\text { Recently burned landscapes may be } \\
\text { viewed negatively by recreationists } \\
\text { and others seeking to enjoy forest } \\
\text { landscapes, although aesthetically and } \\
\text { ecologically desirable conditions can } \\
\text { be enhanced by fire over the long } \\
\text { term. Trade-offs in competing values } \\
\text { and activities will be needed to 'live } \\
\text { with fire' in fire-prone landscapes. }\end{array}$ & $\begin{array}{c}{[94,101,130,136,152,154-} \\
157]\end{array}$ \\
\hline
\end{tabular}

\section{References}

1. IPBES (Ed.) Summary for Policymakers of the Regional Assessment Report on Biodiversity and Ecosystem Services for the Americas of the Intergovernmental Science-Policy Platform on Biodiversity and Ecosystem Services; IPBES Secretariat: Bonn, Germany, 2018 ; p. 41.

2. USDA Forest Service. Future of America's Forest and Rangelands: Forest Service 2010 Resources Planning Act Assessment; GTR-WO-87; USDA Forest Service: Washington, DC, USA, 2012; p. 198.

3. Graham, R.T.; Jain, T.B.; Haynes, R.A.; Sanders, J.; Cleaves, D.L. Assessments for ecological stewardship. In Ecological Stewardship: A common Reference for Ecosystem Management; Sexton, W.T., Malk, A.J., Szaro, R.C., Johnson, N.C., Eds.; Elsevier Science Ltd.: Oxford, UK, 1999; Volume 3, pp. 535-549.

4. Potschin, M.B.; Haines-Young, R.H. Ecosystem services: Exploring a geographical perspective. Prog. Phys. Geogr. 2011, 35, 575-594. [CrossRef]

5. La Notte, A.; D’Amato, D.; Mäkinen, H.; Paracchini, M.L.; Liquete, C.; Egoh, B.; Geneletti, D.; Crossman, N.D. Ecosystem services classification: A systems ecology perspective of the cascade framework. Ecol. Indic. 2017, 74, 392-402. [CrossRef]

6. Levin, S.A.; Lubchenco, J. Resilience, robustness, and marine ecosystem-based management. Bioscience 2008, 58, 27-32. [CrossRef]

7. Müller, F.; de Groot, R.; Willemen, L. Ecosystem services at the landscape scale: The need for integrative approaches. Landsc. Online 2010, 23, 1-11. [CrossRef]

8. Levin, P.S.; Fogarty, M.J.; Murawski, S.A.; Fluharty, D. Integrated ecosystem assessments: Developing the scientific basis for ecosystem-based management of the ocean. PLoS Biol. 2009, 7, e1000014. [CrossRef]

9. DeFries, R.; Nagendra, H. Ecosystem management as a wicked problem. Science 2017, 356, 265-270. [CrossRef]

10. Christensen, N.L.; Bartuska, A.M.; Brown, J.H.; Carpenter, S.; D'Antonio, C.; Francis, R.; Franklin, J.F.; MacMahon, J.A.; Noss, R.F.; Parsons, D.J. The report of the Ecological Society of America committee on the scientific basis for ecosystem management. Ecol. Appl. 1996, 6, 665-691. [CrossRef]

11. Stephens, S.L.; Kobziar, L.N.; Collins, B.M.; Davis, R.; Fulé, P.Z.; Gaines, W.; Ganey, J.; Guldin, J.M.; Hessburg, P.F.; Hiers, K.; et al. Is fire "for the birds"? How two rare species influence fire management across the US. Front. Ecol. Environ. 2019, 17, 391-399. [CrossRef]

12. Millennium Ecosystem Assessment. Ecosystems and Human Well-Being: The Assessment Series (Four Volumes and Summary); Island Press: Washington, DC, USA, 2005.

13. Haines-Young, R.; Potschin, M. The links between biodiversity, ecosystem services and human well-being. In Ecosystem Ecology: A New Synthesis; Raffaelli, D., Frid, C., Eds.; Cambridge University Press: Cambridge, UK, 2010; pp. 110-139.

14. Bruins, R.J.; Canfield, T.J.; Duke, C.; Kapustka, L.; Nahlik, A.M.; Schäfer, R.B. Using ecological production functions to link ecological processes to ecosystem services. Integr. Environ. Assess. Manage. 2017, 13, 52-61. [CrossRef] [PubMed]

15. Cowling, R.M.; Egoh, B.; Knight, A.T.; O’Farrell, P.J.; Reyers, B.; Rouget, M.; Roux, D.J.; Welz, A.; Wilhelm-Rechman, A. An operational model for mainstreaming ecosystem services for implementation. Proc. Natl. Acad. Sci. USA 2008, 105, 9483-9488. [CrossRef]

16. Baldwin, R.F.; Trombulak, S.C.; Leonard, P.B.; Noss, R.F.; Hilty, J.A.; Possingham, H.P.; Scarlett, L.; Anderson, M.G. The Future of Landscape Conservation. Bioscience 2018, 68, 60-63. [CrossRef] [PubMed]

17. Kremen, C.; Ostfeld, R.S. A call to ecologists: Measuring, analyzing, and managing ecosystem services. Front. Ecol. Environ. 2005, 3, 540-548. [CrossRef]

18. Carpenter, S.R.; Mooney, H.A.; Agard, J.; Capistrano, D.; DeFries, R.S.; Díaz, S.; Dietz, T.; Duraiappah, A.K.; Oteng-Yeboah, A.; Pereira, H.M.; et al. Science for managing ecosystem services: Beyond the Millennium Ecosystem Assessment. Proc. Natl. Acad. Sci. USA 2009, 106, 1305-1312. [CrossRef] 
19. Turner, B.L.; Kasperson, R.E.; Matson, P.A.; McCarthy, J.J.; Corell, R.W.; Christensen, L.; Eckley, N.; Kasperson, J.X.; Luers, A.; Martello, M.L.; et al. A framework for vulnerability analysis in sustainability science. Proc. Natl. Acad. Sci. USA 2003, 100, 8074-8079. [CrossRef]

20. Dawson, T.P.; Jackson, S.T.; House, J.I.; Prentice, I.C.; Mace, G.M. Beyond predictions: Biodiversity conservation in a changing climate. Science 2011, 332, 53-58. [CrossRef] [PubMed]

21. Thompson, M.P.; Calkin, D.E. Uncertainty and risk in wildland fire management: A review. J. Environ. Manag. 2011, 92, 1895-1909. [CrossRef] [PubMed]

22. Turner, B.L. Vulnerability and resilience: Coalescing or paralleling approaches for sustainability science? Glob. Environ. Chang. 2010, 20, 570-576. [CrossRef]

23. Munns, W.R., Jr.; Rea, A.W.; Suter, G.W., II; Martin, L.; Blake-Hedges, L.; Crk, T.; Davis, C.; Ferreira, G.; Jordan, S.; Mahoney, M.; et al. Ecosystem services as assessment endpoints for ecological risk assessment. Integr. Environ. Assess. Manag. 2016, 12, 522-528. [CrossRef]

24. Chan, K.M.; Shaw, M.R.; Cameron, D.R.; Underwood, E.C.; Daily, G.C. Conservation planning for ecosystem services. PLoS Biol. 2006, 4, e379. [CrossRef] [PubMed]

25. Thomas, C.D.; Anderson, B.J.; Moilanen, A.; Eigenbrod, F.; Heinemeyer, A.; Quaife, T.; Roy, D.B.; Gillings, S.; Armsworth, P.R.; Gaston, K.J. Reconciling biodiversity and carbon conservation. Ecol. Lett. 2013, 16, 39-47. [CrossRef] [PubMed]

26. Leonard, P.B.; Baldwin, R.F.; Hanks, R.D. Landscape-scale conservation design across biotic realms: Sequential integration of aquatic and terrestrial landscapes. Sci. Rep. 2017, 7, 14556. [CrossRef]

27. Rieb, J.T.; Chaplin-Kramer, R.; Daily, G.C.; Armsworth, P.R.; Böhning-Gaese, K.; Bonn, A.; Cumming, G.S.; Eigenbrod, F.; Grimm, V.; Jackson, B.M.; et al. When, Where, and How Nature Matters for Ecosystem Services: Challenges for the Next Generation of Ecosystem Service Models. Bioscience 2017, 67, 820-833. [CrossRef]

28. Bagstad, K.J.; Villa, F.; Batker, D.; Harrison-Cox, J.; Voigt, B.; Johnson, G.W. From theoretical to actual ecosystem services: Mapping beneficiaries and spatial flows in ecosystem service assessments. Ecol. Soc. 2014, 19, 64. [CrossRef]

29. Schröter, M.; Barton, D.N.; Remme, R.P.; Hein, L. Accounting for capacity and flow of ecosystem services: A conceptual model and a case study for Telemark, Norway. Ecol. Indic. 2014, 36, 539-551. [CrossRef]

30. Bennett, E.M.; Peterson, G.D.; Gordon, L.J. Understanding relationships among multiple ecosystem services. Ecol. Lett. 2009, 12, 1394-1404. [CrossRef] [PubMed]

31. Nelson, E.; Mendoza, G.; Regetz, J.; Polasky, S.; Tallis, H.; Cameron, D.R.; Chan, K.M.A.; Daily, G.C.; Goldstein, J.; Kareiva, P.M.; et al. Modeling multiple ecosystem services, biodiversity conservation, commodity production, and tradeoffs at landscape scales. Front. Ecol. Environ. 2009, 7, 4-11. [CrossRef]

32. Schröter, D.; Cramer, W.; Leemans, R.; Prentice, I.C.; Araujo, M.B.; Arnell, N.W.; Bondeau, A.; Bugmann, H.; Carter, T.R.; Gracia, C.A.; et al. Ecosystem service supply and vulnerability to global change in Europe. Science 2005, 310, 1333-1337. [CrossRef]

33. Mouchet, M.A.; Lamarque, P.; Martín-López, B.; Crouzat, E.; Gos, P.; Byczek, C.; Lavorel, S. An interdisciplinary methodological guide for quantifying associations between ecosystem services. Glob. Environ. Chang. 2014, 28, 298-308. [CrossRef]

34. Moore, D.W.; Booth, P.; Alix, A.; Apitz, S.E.; Forrow, D.; Huber-Sannwald, E.; Jayasundara, N. Application of ecosystem services in natural resource management decision making. Integr. Environ. Assess. Manag. 2017, 13, 74-84. [CrossRef]

35. Egoh, B.; Reyers, B.; Rouget, M.; Richardson, D.M.; Le Maitre, D.C.; van Jaarsveld, A.S. Mapping ecosystem services for planning and management. Agric. Ecosyst. Environ. 2008, 127, 135-140. [CrossRef]

36. Hunter, M.; Westgate, M.; Barton, P.; Calhoun, A.; Pierson, J.; Tulloch, A.; Beger, M.; Branquinho, C.; Caro, T.; Gross, J. Two roles for ecological surrogacy: Indicator surrogates and management surrogates. Ecol. Indic. 2016, 63, 121-125. [CrossRef]

37. Wurtzebach, Z.; Schultz, C. Measuring Ecological Integrity: History, Practical Applications, and Research Opportunities. Bioscience 2016, 66, 446-457. [CrossRef]

38. Kupschus, S.; Schratzberger, M.; Righton, D. Practical implementation of ecosystem monitoring for the ecosystem approach to management. J. Appl. Ecol. 2016, 53, 1236-1247. [CrossRef]

39. Jones, K.B.; Riitters, K.H.; Wickham, J.D.; Tankersley, R.D., Jr.; O’Neill, R.V.; Chaloud, D.J.; Smith, E.R.; Neale, A.C. An Ecological Assessment of the United States Mid-Atlantic Region: A Landscape Atlas; EPA/600/R-97/130; United States Environmental Protection Agency Office of Research and Development: Washington, DC, USA, 1997.

40. Anderson, M.G.; Clark, M.; Sheldon, A.O. Resilient Sites for Terrestrial Conservation in the Northeast and Mid-Atlantic Region; The Nature Conservancy, Eastern Conservation Science: Boston, MA, USA, 2012; p. 168.

41. Theobald, D.M. A general model to quantify ecological integrity for landscape assessments and US application. Landsc. Ecol. 2013, 28, 1859-1874. [CrossRef]

42. Hak, J.C.; Comer, P.J. Modeling landscape condition for biodiversity assessment-Application in temperate North America. Ecol. Indic. 2017, 82, 206-216. [CrossRef]

43. Cleland, D.; Reynolds, K.; Vaughan, R.; Schrader, B.; Li, H.; Laing, L. Terrestrial Condition Assessment for National Forests of the USDA Forest Service in the Continental US. Sustainability 2017, 9, 2144. [CrossRef]

44. Carter, S.K.; Fleishman, E.; Leinwand, I.I.F.; Flather, C.H.; Carr, N.B.; Fogarty, F.A.; Leu, M.; Noon, B.R.; Wohlfeil, M.E.; Wood, D.J.A. Quantifying Ecological Integrity of Terrestrial Systems to Inform Management of Multiple-Use Public Lands in the United States. Environ. Manag. 2019, 64, 1-19. [CrossRef] [PubMed] 
45. O'Brien, A.; Townsend, K.; Hale, R.; Sharley, D.; Pettigrove, V. How is ecosystem health defined and measured? A critical review of freshwater and estuarine studies. Ecol. Indic. 2016, 69, 722-729. [CrossRef]

46. Quinlan, A.E.; Berbés-Blázquez, M.; Haider, L.J.; Peterson, G.D. Measuring and assessing resilience: Broadening understanding through multiple disciplinary perspectives. J. Appl. Ecol. 2016, 53, 677-687. [CrossRef]

47. Meyer, S.T.; Koch, C.; Weisser, W.W. Towards a standardized Rapid Ecosystem Function Assessment (REFA). Trends Ecol. Evol. 2015, 30, 390-397. [CrossRef] [PubMed]

48. Boerema, A.; Rebelo, A.J.; Bodi, M.B.; Esler, K.J.; Meire, P. Are ecosystem services adequately quantified? J. Appl. Ecol. 2017, 54, 358-370. [CrossRef]

49. Folke, C. Resilience: The emergence of a perspective for social-ecological systems analyses. Glob. Environ. Chang. 2006, 16, 253-267. [CrossRef]

50. Seidl, R.; Spies, T.A.; Peterson, D.L.; Stephens, S.L.; Hicke, J.A. Searching for resilience: Addressing the impacts of changing disturbance regimes on forest ecosystem services. J. Appl. Ecol. 2016, 53, 120-129. [CrossRef]

51. McWethy, D.B.; Schoennagel, T.; Higuera, P.E.; Krawchuk, M.; Harvey, B.J.; Metcalf, E.C.; Schultz, C.; Miller, C.; Metcalf, A.L.; Buma, B.; et al. Rethinking resilience to wildfire. Nat. Sustain. 2019, 2, 797-804. [CrossRef]

52. Carpenter, S.; Walker, B.; Anderies, J.M.; Abel, N. From metaphor to measurement: Resilience of what to what? Ecosystems 2001, 4, 765-781. [CrossRef]

53. $\mathrm{Wu}, \mathrm{J}$. Landscape sustainability science: Ecosystem services and human well-being in changing landscapes. Landsc. Ecol. 2013, 28, 999-1023. [CrossRef]

54. Elmqvist, T.; Folke, C.; Nyström, M.; Peterson, G.; Bengtsson, J.; Walker, B.; Norberg, J. Response diversity, ecosystem change, and resilience. Front. Ecol. Environ. 2003, 1, 488-494. [CrossRef]

55. Costanza, R.; Mageau, M. What is a healthy ecosystem? Aquat. Ecol. 1999, 33, 105-115. [CrossRef]

56. Scheffer, M.; Carpenter, S.; Foley, J.A.; Folke, C.; Walker, B. Catastrophic shifts in ecosystems. Nature 2001, 413, 591-596. [CrossRef]

57. Angeler, D.G.; Allen, C.R. Quantifying resilience. J. Appl. Ecol. 2016, 53, 617-624. [CrossRef]

58. Miller, F.; Osbahr, H.; Boyd, E.; Thomalla, F.; Bharwani, S.; Ziervogel, G.; Walker, B.; Birkmann, J.; Van der Leeuw, S.; Rockström, J. Resilience and vulnerability: Complementary or conflicting concepts? Ecol. Soc. 2010, 15, 1-25. [CrossRef]

59. Munns Jr, W.R.; Rea, A.W.; Mazzotta, M.J.; Wainger, L.A.; Saterson, K. Toward a standard lexicon for ecosystem services. Integr. Environ. Assess. Manag. 2015, 11, 666-673. [CrossRef] [PubMed]

60. Wilson, B.T.; Woodall, C.W.; Griffith, D.M. Imputing forest carbon stock estimates from inventory plots to a nationally continuous coverage. Carbon Balance Manag. 2013, 8, 1. [CrossRef]

61. USDA Forest Service. Forests to Faucets. Available online: https://www.fs.fed.us/ecosystemservices/FS_Efforts/forests2faucets. shtml (accessed on 24 March 2021).

62. eBird. eBird Basic Dataset; Version: EBD_relMay-2013; Cornell Lab of Ornithology: Ithaca, NY, USA, 2013.

63. USGS Gap Analysis Program. Protected Areas Database of the United States (PAD-US), version 1.4; United States Geological Survey: Boise, ID, USA, 2016.

64. Krist, F.J.; Ellenwood, J.R.; Woods, M.E.; McMahan, A.J.; Cowardin, J.P.; Ryerson, D.E.; Sapio, F.J.; Zweifler, M.O.; Romero, S.A. 2013-2027 National Insect and Disease Forest Risk Assessment; FHTET-14-01; USDA Forest Service Forest Health Technology Enterprise Team: Fort Collins, CO, USA, 2014.

65. Evans, J.S.; Kiesecker, J.M. Shale Gas, Wind and Water: Assessing the Potential Cumulative Impacts of Energy Development on Ecosystem Services within the Marcellus Play. PLoS ONE 2014, 9, e89210. [CrossRef] [PubMed]

66. Dunscomb, J.K.; Evans, J.S.; Strager, J.M.; Strager, M.P.; Kiesecker, J.M. Assessing Future Energy Development across the Appalachian Landscape Conservation Cooperative; The Nature Conservancy: Charlottesville, VA, USA, 2014; p. 48.

67. Radeloff, V.C.; Stewart, S.I.; Hawbaker, T.J.; Gimmi, U.; Pidgeon, A.M.; Flather, C.H.; Hammer, R.B.; Helmers, D.P. Housing growth in and near United States protected areas limits their conservation value. Proc. Natl. Acad. Sci. USA 2010, 107, 940-945. [CrossRef] [PubMed]

68. USDA Forest Service. National Report on Sustainable Forests-2010; FS-979; USDA Forest Service: Washington, DC, USA, 2011; 214p.

69. Boettner, F.; Clingerman, J.; Mcilmoil, R.; Hansen, E.; Hartz, L.; Hereford, A.; Vanderberg, M.; Arano, K.; Deng, J.; Strager, J.; et al. An Assessment of Natural Assets in the Appalachian Region: Forest Resources; Appalachian Regional Commission: Washington, DC, USA, 2014.

70. Giakoumi, S.; Halpern, B.S.; Michel, L.N.; Gobert, S.; Sini, M.; Boudouresque, C.F.; Gambi, M.C.; Katsanevakis, S.; Lejeune, P.; Montefalcone, M. Towards a framework for assessment and management of cumulative human impacts on marine food webs. Conserv. Biol. 2015, 29, 1228-1234. [CrossRef] [PubMed]

71. Mageau, M.T.; Costanza, R.; Ulanowicz, R.E. Quantifying the trends expected in developing ecosystems. Ecol. Model. 1998, 112, 1-22. [CrossRef]

72. Dee, L.E.; Allesina, S.; Bonn, A.; Eklöf, A.; Gaines, S.D.; Hines, J.; Jacob, U.; McDonald-Madden, E.; Possingham, H.; Schröter, M.; et al. Operationalizing Network Theory for Ecosystem Service Assessments. Trends Ecol. Evol. 2017, 32, 118-130. [CrossRef]

73. Ings, T.C.; Montoya, J.M.; Bascompte, J.; Blüthgen, N.; Brown, L.; Dormann, C.F.; Edwards, F.; Figueroa, D.; Jacob, U.; Jones, J.I.; et al. Review: Ecological networks—Beyond food webs. J. Anim. Ecol. 2009, 78, 253-269. [CrossRef]

74. Parrott, L. Measuring ecological complexity. Ecol. Indic. 2010, 10, 1069-1076. [CrossRef] 
75. Ulanowicz, R.E. Ecology, the Ascendent Perspective; Columbia University Press: New York, NY, USA, 1997.

76. Zaccarelli, N.; Li, B.-L.; Petrosillo, I.; Zurlini, G. Order and disorder in ecological time-series: Introducing normalized spectral entropy. Ecol. Indic. 2013, 28, 22-30. [CrossRef]

77. Ulanowicz, R.E.; Goerner, S.J.; Lietaer, B.; Gomez, R. Quantifying sustainability: Resilience, efficiency and the return of information theory. Ecol. Complex. 2009, 6, 27-36. [CrossRef]

78. Plieninger, T.; van der Horst, D.; Schleyer, C.; Bieling, C. Sustaining ecosystem services in cultural landscapes. Ecol. Soc. 2014, 19. [CrossRef]

79. Pfeifer, M.; Disney, M.; Quaife, T.; Marchant, R. Terrestrial ecosystems from space: A review of earth observation products for macroecology applications. Global Ecol. Biogeogr. 2012, 21, 603-624. [CrossRef]

80. Kerr, J.T.; Ostrovsky, M. From space to species: Ecological applications for remote sensing. Trends Ecol. Evol. 2003, 18, 299-305. [CrossRef]

81. Pereira, H.M.; Ferrier, S.; Walters, M.; Geller, G.N.; Jongman, R.; Scholes, R.J.; Bruford, M.W.; Brummitt, N.; Butchart, S.; Cardoso, A. Essential biodiversity variables. Science 2013, 339, 277-278. [CrossRef] [PubMed]

82. Morisette, J.T.; Richardson, A.D.; Knapp, A.K.; Fisher, J.I.; Graham, E.A.; Abatzoglou, J.; Wilson, B.E.; Breshears, D.D.; Henebry, G.M.; Hanes, J.M. Tracking the rhythm of the seasons in the face of global change: Phenological research in the 21st century. Front. Ecol. Environ. 2009, 7, 253-260. [CrossRef]

83. Kennedy, R.E.; Andréfouët, S.; Cohen, W.B.; Gómez, C.; Griffiths, P.; Hais, M.; Healey, S.P.; Helmer, E.H.; Hostert, P.; Lyons, M.B Bringing an ecological view of change to Landsat-based remote sensing. Front. Ecol. Environ. 2014, 12, 339-346. [CrossRef]

84. Wear, D.N.; Greis, J.G. The Southern Forest Futures Project: Technical Report; SRS-178; US Department of Agriculture Forest Service: Asheville, NC, USA, 2013; p. 542.

85. Reynolds, K.M. Integrated decision support for sustainable forest management in the United States: Fact or fiction? Comput. Electron. Agric. 2005, 49, 6-23. [CrossRef]

86. Brandt, L.A.; Butler, P.R.; Handler, S.D.; Janowiak, M.K.; Shannon, P.D.; Swanston, C.W. Integrating science and management to assess forest ecosystem vulnerability to climate change. J. For. 2017, 115, 212-221. [CrossRef]

87. Naugle, D.E.; Allred, B.W.; Jones, M.O.; Twidwell, D.; Maestas, J.D. Coproducing Science to Inform Working Lands: The Next Frontier in Nature Conservation. Bioscience 2019, 70, 90-96. [CrossRef]

88. Landscape Conservation Cooperative Network. Landscape Conservation Cooperative Network Strategic Plan. 2014, p. 20. Available online: http:/ / lccnetwork.org/strategic-plan (accessed on 1 May 2017).

89. Chamberlain, J.L.; Emery, M.R.; Patel-Weynand, T. (Eds.) Assessment of Nontimber Forest Products in the United States under Changing Conditions; General Technical Report SRS-232; USDA Forest Service, Southern Research Station: Asheville, NC, USA, 2018 ; p. 268.

90. US Environmental Protection Agency. EPA's 2008 Report on the Environment; EPA/600/R-07/045F; National Center for Environmental Assessment: Washington, DC, USA, 2008.

91. US Environmental Protection Agency. EPA's Report on the Environment (ROE). Available online: https://www.epa.gov/reportenvironment (accessed on 30 January 2017).

92. Shifley, S.R.; Aguilar, F.X.; Song, N.; Stewart, S.I.; Nowak, D.J.; Gormanson, D.D.; Moser, W.K.; Wormstead, S.; Greenfield, E.J. Forests of the Northern United States; Gen. Tech. Rep. NRS-90; U.S. Department of Agriculture, Forest Service, Northern Research Station: Newtown Square, PA, USA, 2012; p. 254.

93. USDA Forest Service. Future of America's Forest and Rangelands: Update to the Forest Service 2010 Resources Planning Act Assessment; GTR-WO-94; USDA Forest Service: Washington, DC, USA, 2016.

94. Keyser, T.; Malone, J.; Cotton, C.; Lewis, J. Outlook for Appalachian-Cumberland Forests: A subregional Report from the Southern Forest Futures Project; General Technical Report SRS-188; USDA Forest Service, Southern Research Station: Asheville, NC, USA, 2014.

95. McCaskill, G.L.; McWilliams, W.H.; Alerich, C.A.; Butler, B.J.; Crocker, S.J.; Domke, G.M.; Griffith, D.; Kurtz, C.M.; Lehman, S.; Lister, T.W.; et al. Pennsylvania's Forests, 2009; Resour. Bull. NRS-82; USDA Forest Service, Northern Research Station: Newtown Square, PA, USA, 2013.

96. Woodall, C.W.; Webb, M.N.; Wilson, B.T.; Settle, J.; Piva, R.J.; Perry, C.H.; Meneguzzo, D.M.; Crocker, S.J.; Butler, B.J.; Hansen, M.; et al. Indiana's Forests, 2008; Resour. Bull. NRS-90; USDA Forest Service, Northern Research Station: Newtown Square, PA, USA, 2011.

97. Brown, M.J.; New, B.D.; Johnson, T.G.; Chamberlain, J.L. North Carolina's Forests, 2007; Resour. Bull. SRS-RB-199; USDA Forest Service, Southern Research Station: Asheville, NC, USA, 2014.

98. New York State Department of Environmental Conservation. Forest Resource Assessment and Strategy: Keeping New York's Forests as Forests; New York State Department of Environmental Conservation: Albany, NY, USA, 2010; p. 253.

99. Ohio Department of Natural Resources. Ohio's Statewide Forest Resource Assessment-2010; Ohio Department of Natural Resources: Columbus, OH, USA, 2010.

100. Alabama Forestry Commission. Forests at the Crossroads: Alabama's Forest Assessment and Resource Strategy; Alabama Forestry Commission: Montgomery, AL, USA, 2010.

101. Hanson, C.; Yonavjak, L.; Clarke, C.; Minnemeyer, S.; Boisrobert, L.; Leach, A.; Schleeweis, K. Southern Forests For the Future; World Resources Institute: Washington, DC, USA, 2010. 
102. Boettner, F.; Hansen, E.; Clingerman, J.; Hereford, A.; Zegre, S.; Martin, R.; Askins, N.; Deng, J.; Abdalla, C.; Goetz, S.J. An Assessment of Natural Assets in the Appalachian Region: Water Resources; Appalachian Regional Commission: Washington, DC, USA, 2014.

103. Butler, P.; Iverson, L.; Thompson, F.R., III; Brandt, L.; Handler, S.; Janowiak, M.; Shannon, P.D.; Swanston, C.; Karriker, K.; Bartig, J.; et al. Central Appalachians Ecosystem Vulnerability Assessment and Synthesis: A Report from the Central Appalachians Climate Change Response Framework Project; Gen. Tech. Rep. NRS-146; USDA Forest Service, Northern Research Station: Newtown Square, PA, USA, 2015; p. 254.

104. Brandt, L.; He, H.; Iverson, L.; Thompson, F.R., III; Butler, P.; Handler, S.; Janowiak, M.; Shannon, P.D.; Swanston, C.; Albrecht, M.; et al. Central Hardwoods Ecosystem Vulnerability Assessment and Synthesis: A Report from the Central Hardwoods Climate Change Response Framework Project; Gen. Tech. Rep. NRS-124; USDA Forest Service, Northern Research Station: Newtown Square, PA, USA, 2014; p. 254.

105. SAMAB (Southern Appalachian Man and the Biosphere). The Southern Appalachian Assessment: Reports 1-5; US Department of Agriculture, Forest Service: Atlanta, GA, USA, 1996.

106. Wickham, J.D.; O’Neill, R.V.; Riitters, K.H.; Smith, E.R.; Wade, T.G.; Jones, K.B. Geographic targeting of increases in nutrient export due to future urbanization. Ecol. Appl. 2002, 12, 93-106. [CrossRef]

107. Gardiner, E.P.; Sutherland, A.B.; Bixby, R.J.; Scott, M.C.; Meyer, J.L.; Helfman, G.S.; Benfield, E.F.; Pringle, C.M.; Bolstad, P.V.; Wear, D.N. Linking stream and landscape trajectories in the southern Appalachians. Environ. Monit. Assess. 2009, 156, 17-36. [CrossRef] [PubMed]

108. Huggett, R.; Wear, D.; Li, R.; Coulston, J.; Liu, S. Forecasts of forest conditions. In The Southern Forest Futures Project: Technical Report; Gen. Tech. Rep. SRS-178; Wear, D.N., Greis, J.G., Eds.; US Department of Agriculture Forest Service, Southern Research Station: Asheville, NC, USA, 2013; pp. 73-101.

109. Lockaby, G.; Nagy, C.; Vose, J.M.; Ford, C.R.; Sun, G.; McNulty, S.; Caldwell, P.; Cohen, E.; Moore Myers, J. Forests and Water. In The Southern Forest Futures Project: Technical Report; Gen. Tech. Rep. SRS-178; Wear, D.N., Greis, J.G., Eds.; US Department of Agriculture Forest Service, Southern Research Station: Asheville, NC, USA, 2013; pp. 309-339.

110. Wickham, J.D.; Flather, C.H. Integrating biodiversity and drinking water protection goals through geographic analysis. Divers. Distrib. 2013, 19, 1198-1207. [CrossRef]

111. Coulston, J.W.; Wear, D.N.; Vose, J.M. Complex forest dynamics indicate potential for slowing carbon accumulation in the southeastern United States. Sci. Rep. 2015, 5, 8002. [CrossRef]

112. Wear, D.; Huggett, R.; Li, R.; Perryman, B.; Liu, S. Forecasts of Forest Conditions in Regions of the United States under Future Scenarios: A Technical Document Supporting the Forest Service 2012 RPA Assessment; Gen. Tech. Rep. SRS-170; US Department of Agriculture Forest Service, Southern Research Station: Asheville, NC, USA, 2013; p. 101.

113. SAMAB (Southern Appalachian Man and the Biosphere). The Southern Appalachian Assessment: Aquatic Technical Report; Report 2 of 5; US Department of Agriculture, Forest Service: Atlanta, GA, USA, 1996.

114. Merricks, T.C.; Cherry, D.S.; Zipper, C.E.; Currie, R.J.; Valenti, T.W. Coal-mine hollow fill and settling pond influences on headwater streams in southern West Virginia, USA. Environ. Monit. Assess. 2007, 129, 359-378. [CrossRef] [PubMed]

115. Zipper, C.; Burger, J.; McGrath, J.; Amichev, B. Carbon accumulation potentials of post-SMCRA coal-mined lands. In Proceedings of the 24th Annual National Conference of the American Society of Mining and Reclamation, Gillette, Wyoming, 2-7 June 2007; American Society of Mining and Reclamation: Lexington, KY, USA, 2007; pp. 962-980.

116. Amichev, B.Y.; Burger, J.A.; Rodrigue, J.A. Carbon sequestration by forests and soils on mined land in the Midwestern and Appalachian coalfields of the U.S. For. Ecol. Manag. 2008, 256, 1949-1959. [CrossRef]

117. Pond, G.J.; Passmore, M.E.; Borsuk, F.A.; Reynolds, L.; Rose, C.J. Downstream effects of mountaintop coal mining: Comparing biological conditions using family-and genus-level macroinvertebrate bioassessment tools. J. N. Am. Benthol. Soc. 2008, 27, 717-737. [CrossRef]

118. Townsend, P.A.; Helmers, D.P.; Kingdon, C.C.; McNeil, B.E.; de Beurs, K.M.; Eshleman, K.N. Changes in the extent of surface mining and reclamation in the Central Appalachians detected using a 1976-2006 Landsat time series. Remote Sens. Environ. 2009, 113, 62-72. [CrossRef]

119. Fritz, K.M.; Fulton, S.; Johnson, B.R.; Barton, C.D.; Jack, J.D.; Word, D.A.; Burke, R.A. Structural and functional characteristics of natural and constructed channels draining a reclaimed mountaintop removal and valley fill coal mine. J. N. Am. Benthol. Soc. 2010, 29, 673-689. [CrossRef]

120. Lindberg, T.T.; Bernhardt, E.S.; Bier, R.; Helton, A.; Merola, R.B.; Vengosh, A.; Di Giulio, R.T. Cumulative impacts of mountaintop mining on an Appalachian watershed. Proc. Natl. Acad. Sci. USA 2011, 108, 20929-20934. [CrossRef] [PubMed]

121. Zipper, C.; Burger, J.; Skousen, J.; Angel, P.; Barton, C.; Davis, V.; Franklin, J. Restoring Forests and Associated Ecosystem Services on Appalachian Coal Surface Mines. Environ. Manag. 2011, 47, 751-765. [CrossRef] [PubMed]

122. Campbell, J.E.; Fox, J.F.; Acton, P.M. Terrestrial carbon losses from mountaintop coal mining offset regional forest carbon sequestration in the 21st century. Environ. Res. Lett. 2012, 7, 045701. [CrossRef]

123. Wickham, J.; Wood, P.B.; Nicholson, M.C.; Jenkins, W.; Druckenbrod, D.; Suter, G.W.; Strager, M.P.; Mazzarella, C.; Galloway, W.; Amos, J. The overlooked terrestrial impacts of mountaintop mining. Bioscience 2013, 63, 335-348. [CrossRef]

124. Hitt, N.P.; Chambers, D.B. Temporal changes in taxonomic and functional diversity of fish assemblages downstream from mountaintop mining. Freshw. Sci. 2014, 33, 915-926. [CrossRef] 
125. Daniel, W.M.; Infante, D.M.; Hughes, R.M.; Tsang, Y.-P.; Esselman, P.C.; Wieferich, D.; Herreman, K.; Cooper, A.R.; Wang, L.; Taylor, W.W. Characterizing coal and mineral mines as a regional source of stress to stream fish assemblages. Ecol. Indic. 2015, 50, 50-61. [CrossRef]

126. Ford, C.R.; Laseter, S.H.; Swank, W.T.; Vose, J.M. Can forest management be used to sustain water-based ecosystem services in the face of climate change? Ecol. Appl. 2011, 21, 2049-2067. [CrossRef]

127. McNulty, S.; Caldwell, P.; Doyle, T.W.; Johnsen, K.; Liu, Y.; Mohan, J.; Prestemon, J.; Sun, G. Forests and climate change in the southeast USA. In Climate of the Southeast United States: Variability, Change, Impacts, and Vulnerability; Ingram, K., Dow, K., Carter, L., Anderson, J., Eds.; Island Press: Washington, DC, USA, 2013; pp. 165-189.

128. Brzostek, E.R.; Dragoni, D.; Schmid, H.P.; Rahman, A.F.; Sims, D.; Wayson, C.A.; Johnson, D.J.; Phillips, R.P. Chronic water stress reduces tree growth and the carbon sink of deciduous hardwood forests. Global Change Biol. 2014, 20, 2531-2539. [CrossRef]

129. Hwang, T.; Band, L.E.; Miniat, C.F.; Song, C.; Bolstad, P.V.; Vose, J.M.; Love, J.P. Divergent phenological response to hydroclimate variability in forested mountain watersheds. Global Change Biol. 2014, 20, 2580-2595. [CrossRef]

130. Liu, Y.; Prestemon, J.P.; Goodrick, S.L.; Holmes, T.P.; Stanturf, J.A.; Vose, J.M.; Sun, G. Future Wildfire Trends, Impacts, and Mitigation Options in the Southern United States. In Climate Change Adaptation and Mitigation Management Options: A Guide for Natural Resource Managers in Southern Forest Ecosystems; Vose, J.M., Klepzig, K.D., Eds.; CRC Press, Taylor \& Francis Group: Boca Raton, FL, USA, 2014; pp. 85-126.

131. Ford, C.R.; Vose, J.M. Tsuga canadensis (L.) Carr. mortality will impact hydrologic processes in southern Appalachian forest ecosystems. Ecol. Appl. 2007, 17, 1156-1167. [CrossRef]

132. Hicke, J.A.; Allen, C.D.; Desai, A.R.; Dietze, M.C.; Hall, R.J.; Kashian, D.M.; Moore, D.; Raffa, K.F.; Sturrock, R.N.; Vogelmann, J. Effects of biotic disturbances on forest carbon cycling in the United States and Canada. Glob. Chang. Biol. 2012, 18, 7-34.

133. Brantley, S.T.; Miniat, C.F.; Elliott, K.J.; Laseter, S.H.; Vose, J.M. Changes to southern Appalachian water yield and stormflow after loss of a foundation species. Ecohydrology 2015, 8, 518-528. [CrossRef]

134. Vose, J.M.; Wear, D.N.; Mayfield, A.E.; Nelson, C.D. Hemlock woolly adelgid in the southern Appalachians: Control strategies, ecological impacts, and potential management responses. For. Ecol. Manag. 2013, 291, 209-219. [CrossRef]

135. Vose, J.M.; Swank, W.T.; Clinton, B.D.; Knoepp, J.D.; Swift, L.W. Using stand replacement fires to restore southern Appalachian pine-hardwood ecosystems: Effects on mass, carbon, and nutrient pools. For. Ecol. Manag. 1999, 114, 215-226. [CrossRef]

136. Stanturf, J.A.; Goodrick, S.L. Fire. In The Southern Forest Futures Project: Technical Report; Gen. Tech. Rep. SRS-178; Wear, D.N., Greis, J.G., Eds.; US Department of Agriculture Forest Service, Southern Research Station: Asheville, NC, USA, 2013 ; pp. 509-542.

137. Downey, D.M.; Haraldstatdt, J.P.; Fisher, S.N. Water chemistry of North Branch Simpson Creek and the Rich Hole Wilderness fire In Wildland Fire in the Appalachians: Discussions among Managers and Scientists; Gen. Tech. Rep. SRS-199; Waldrop, T.A., Ed.; US Department of Agriculture Forest Service: Asheville, NC, USA, 2014; pp. 113-126.

138. Hayden, L.; Hendricks, S.; Bowker, M.; English, D.; Stremple, N.; Bayless, D. Outdoor recreation demand and supply in the region. In The Southern Appalachian Assessment Social/Cultural/Economic Technical Report; USDA Forest Service, Southern Region: Atlanta, GA, USA, 1996.

139. Jackson, L.E.; Rashleigh, B.; McDonald, M.E. Economic value of stream degradation across the central Appalachians. J. Reg. Anal. Policy 2012, 42, 188-197.

140. Bowker, J.M.; Askew, A. Outlook for Outdoor Recreation in the Northern United States. A Technical Document Supporting the Northern Forest Futures Project with Projections through 2060; Gen. Tech. Rep. NRS-120; USDA Forest Service, Northern Research Station: Newtown Square, PA, USA, 2013; p. 62.

141. Miller, J.H.; Lemke, D.; Coulston, J. The invasion of southern forests by nonnative plants: Current and future occupation, with impacts, management strategies, and mitigation approaches. In The Southern Forest Futures Project: Technical Report; Gen. Tech. Rep. SRS-178; Wear, D.N., Greis, J.G., Eds.; US Department of Agriculture Forest Service, Southern Research Station: Asheville, NC, USA, 2013; pp. 397-456.

142. SAMAB (Southern Appalachian Man and the Biosphere). The Southern Appalachian Assessment: Social, Cultural, and Economic Technical Report; Report 4 of 5; US Department of Agriculture, Forest Service: Atlanta, GA, USA, 1996.

143. Cordell, H.K.; Betz, C.J.; Mou, S.H. Outdoor recreation in a shifting societal landscape. In The Southern Forest Futures Project: Technical Report; Gen. Tech. Rep. SRS-178; Wear, D.N., Greis, J.G., Eds.; US Department of Agriculture Forest Service, Southern Research Station: Asheville, NC, USA, 2013; pp. 123-160.

144. Wickham, J.D.; Riitters, K.H.; Wade, T.G.; Coan, M.; Homer, C. The effect of Appalachian mountaintop mining on interior forest. Landsc. Ecol. 2007, 22, 179-187. [CrossRef]

145. Iverson, L.R.; Prasad, A.M.; Matthews, S.N.; Peters, M. Estimating potential habitat for 134 eastern US tree species under six climate scenarios. For. Ecol. Manag. 2008, 254, 390-406. [CrossRef]

146. Cordell, H.K.; Heboyan, V.; Santos, F.; Bergstrom, J.C. Natural Amenities and Rural Population Migration: A Technical Document Supporting the Forest Service 2010 RPA Assessment; Gen. Tech. Rep. SRS-146; USDA Forest Service, Southern Research Station: Asheville, NC, USA, 2011; p. 23.

147. Lal, P.; Alavalapati, J.R.R.; Mercer, E. Socio-economic impacts of climate change on rural United States. Mitig. Adapt. Strateg. Glob. Chang. 2011, 16, 819-844. [CrossRef] 
148. Prasad, A.M.; Gardiner, J.D.; Iverson, L.R.; Matthews, S.N.; Peters, M. Exploring tree species colonization potentials using a spatially explicit simulation model: Implications for four oaks under climate change. Glob. Chang. Biol. 2013, 19, $2196-2208$. [CrossRef] [PubMed]

149. Matthews, S.N.; Iverson, L.R.; Peters, M.P.; Prasad, A.M.; Subburayalu, S. Assessing and comparing risk to climate changes among forested locations: Implications for ecosystem services. Landsc. Ecol. 2014, 29, 213-228. [CrossRef]

150. Souther, S.; McGraw, J.B. Synergistic effects of climate change and harvest on extinction risk of American ginseng. Ecol. Appl. 2014, 24, 1463-1477. [CrossRef]

151. Duerr, D.A.; Mistretta, P.A. Invasive pests: Insects and diseases. In The Southern Forest Futures Project: Technical Report; Gen. Tech. Rep. SRS-178; Wear, D.N., Greis, J.G., Eds.; US Department of Agriculture Forest Service, Southern Research Station: Asheville, NC, USA, 2013; pp. 457-508.

152. SAMAB (Southern Appalachian Man and the Biosphere). The Southern Appalachian Assessment: Terrestrial Technical Report; Report 5 of 5; US Department of Agriculture, Forest Service: Atlanta, GA, USA, 1996.

153. Ford, C.R.; Elliott, K.J.; Clinton, B.D.; Kloeppel, B.D.; Vose, J.M. Forest dynamics following eastern hemlock mortality in the southern Appalachians. Oikos 2012, 121, 523-536. [CrossRef]

154. Brose, P.; Dey, D.C.; Waldrop, T.A. The Fire-Oak Literature of Eastern North America: Synthesis and Guidelines; Gen. Tech. Rep. NRS-135; USDA Forest Service: Newtown Square, PA, USA, 2014; p. 98.

155. Brose, P.; Schuler, T.; Van Lear, D.; Berst, J. Bringing fire back: The changing regimes of the Appalachian mixed-oak forests. J. For. 2001, 99, 30-35.

156. Brose, P.H.; Dey, D.C.; Phillips, R.J.; Waldrop, T.A. A meta-analysis of the fire-oak hypothesis: Does prescribed burning promote oak reproduction in eastern North America? For. Sci. 2013, 59, 322-334. [CrossRef]

157. Peters, M.P.; Iverson, L.R.; Matthews, S.N.; Prasad, A.M. Wildfire hazard mapping: Exploring site conditions in eastern US wildland-urban interfaces. Int. J. Wildland Fire 2013, 22, 567-578. [CrossRef] 